\title{
OLEIC ACID GLYCERIDES CONTENT IN THE OILS OF MAIZE ENDOSPERMIC MUTANTS AND ITS DEPENDENCE ON TEMPERATURE DURING RIPENING
}

\author{
Dmytro S. Tymchuk ${ }^{1}, \#$, Iurii Sadovnichenko², Nataliya Tymchuk², Halyna Potapenko ${ }^{3}$, \\ and Inna Torianyk ${ }^{4}$ \\ ${ }^{1}$ Kharkiv Institute of Medicine and Biomedical Sciences, Kyiv Medical University, 11 Sadova Str., Kharkiv, 61002, UKRAINE \\ ${ }^{2}$ Kharkiv National Medical University, 4 Nauky Ave., Kharkiv, 61022, UKRAINE \\ ${ }^{3}$ G. S. Skovoroda Kharkiv National Pedagogical University, 2 Valentynivska Str., Kharkiv, 61168, UKRAINE \\ ${ }^{4}$ I. I. Mechnikov Institute of Microbiology and Immunology, 14-16 Pushkinska Str., Kharkiv, 61057, UKRAINE \\ \# Corresponding author, dstymchuk@yahoo.com
}

Communicated by Isaak Rashal

\begin{abstract}
Identification of sources of increased content of oleic acid glycerides (oleates) and determination of the nature of its variability are prerequisites for improving oil quality. The purpose of this study was to establish the variability of the content of oleic acid glycerides (oleates) in maize oil depending on the genotype and ripening temperature. The experiments were carried out on a series of common maize inbreds and inbred-carriers of the $\mathrm{su}_{1}$, ae, and $\mathrm{su}_{2}$ mutations, which were grown for three years. The fatty acid composition of the oil was analysed by the Peisker gas chromatographic method. Genotype-environment interactions were assessed using the Eberhard-

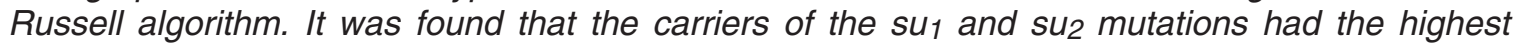
oleate content. The oleate content of maize oil generally increased with increasing ripening temperature. Unrelated inbreds based on one mutation significantly differed in the genetically determined level of oleate and showed non-identical responses to the ripening temperature. In inbreds of the first type, the content of oleates changed significantly with temperature fluctuation, while inbreds of the second type provided a fairly stable level of the trait under these conditions.
\end{abstract}

Keywords: Zea mays L., fatty acid composition of oil, growing conditions.

\section{INTRODUCTION}

High oleic vegetable oils are characterised by increased resistance to lipid peroxidation and, therefore, can be successfully used for prevention and treatment of a number of dangerous human diseases (Karakor and Cam, 2015). In addition, oils of this type are characterised by high technological characteristics, which create opportunities for effective use in the food, pharmaceutical and technical industries (Leao et al., 2016; Yara-Varon et al., 2017; De Alzaa et al., 2018). Therefore, high oleic oils already occupy an important segment of the international oilseed market, and there are prospects for its expansion (Parcell et al., 2018).

Among the oilseeds grown on an industrial scale, which are not subject to special improvement, only European olive
(Olea europaea L.) and cultivated peanuts (Arachis hypogaea L.) have the high content of oleates in oil (Wilson, 2012). However, these crops require specific growing conditions and in many countries of the world high oleic oils are imported products. Therefore, it is necessary to create sources of high oleic oils based on other oilseeds.

It is known that an increase in the content of oleic acid in oil occurs as a result of inhibition of the formation of linoleic acid from oleic acid, catalysed by the specific desaturase FAD-2 (Vanhecke et al., 2013). It was shown that this process has a hereditary nature and an increased content of oleic acid is controlled by recessive alleles of the FAD-2 loci, causing a decrease in the enzyme activity (Dar et al., 2017). To date, using mutations with a similar effect, it has been possible to create a wide genetic diversity in the content of oleates (Gavrilova et al., 2020). 
The main difficulties in detecting high oleic mutations are the absence of their visual markers, and for identification purposes, as a rule, rather complex and not always available molecular genetic methods are used (Long et al., 2018). Therefore, it seems promising to use carriers of such mutations, which would be spatially linked to oleate-coding loci and have reliable visually diagnosed phenotypes. These include, first of all, natural endosperm mutants of maize (Boyer and Hannah, 2001; Cook et al., 2012). Compared with the methods of creating the initial material traditionally used in breeding for oil quality (Murphy, 2014), their use has advantages in terms of economy and environmental safety. It was found that the content of oleates in maize is controlled by a polygenic system (Motto et al., 2010), and three of its most expressive oleate-coding loci are located in chromosomes 4, 5, and 6 (Belo et al., 2008; Wassom et al., 2008; Rajendran et al., 2017), in which some genes of the endosperm structure are also localised, in particular, $s u_{1}, a e$, and $s u_{2}$ (Coe and Schaeffer, 2005).

It has been shown that oleate-coding loci in maize differ significantly in expressivity (Yang et al., 2010) and, therefore, the allelic structure of the polygenic complex is one of the factors that determines the content of oleates in oil. Another factor is the influence of growing conditions, especially the temperature at which oil accumulates. It is known that with higher temperature, the rate of conversion of oleic acid to linoleic acid decreases due to a decrease in the activity of FAD-2 desaturase, which catalyses this process (Li et al., 2015). At the same time, there are data on different changes in the activity of different forms of FAD-2 in maize under the influence of temperature (Zhao et al., 2019) and different expressiveness of FAD-2 loci in forms of the same species under a similar temperature regime of growing (Menard et al., 2017).

The results obtained to date give grounds for assuming the effect of endosperm mutations $s u_{1}, a e$, and $s u_{2}$ on the content of oleates in oil due to their spatial linkage with oleate-coding loci, as well as changes in the trait level in different carriers of these mutations with fluctuations in air temperature in the grain ripening period. The aim of the study was to use established and reliable genetic sources of increased oleate content to determine the nature of the variability of this trait under different growing conditions, an important condition for effective improvement of oil quality.

\section{MATERIALS AND METHODS}

The growing of maize inbreds was carried out at the Breeding and Seed Production Station "NASCO", located in the Novo-Kakhovsky District of Kherson region, located in the steppe zone of Ukraine. The geographic coordinates of the location of the field experiments are $46.7545^{1} \mathrm{~N}$, $33.3486^{1} \mathrm{E}$, height above sea level $-15 \mathrm{~m}$ (http: // time-in-ru/coordinates/nova-kakhovka).
The soils on the experimental plot were southern residual solonetzic light loamy and medium loamy chernozems with a humus content of $1.5 \%$, soil acidity $\mathrm{pH}=6.7$, a weighted average phosphorus content of $8.54 \mathrm{mg} / 100 \mathrm{~g}$ and a potassium content of $21.5 \mathrm{mg} / 100 \mathrm{~g}$. The ecological and agrochemical score of the experimental site was 37 .

The climate of the experiment zone is moderate continental. The frost-free period lasts $8-9$ months a year. The average air temperature during the growing season of maize (AprilSeptember) over the past 50 years was $18.5^{\circ} \mathrm{C}$, and the average annual precipitation was $239 \mathrm{~mm}$. The temperature conditions of the growing season are favourable for the cultivation of maize, but during this period there is a deficiency of atmospheric moisture.

The object of the research was a series of unrelated maize inbreds that were carriers of $s u_{1}, a e$, and $s u_{2}$ endosperm mutations, localised in chromosomes 4,5, and 6, and presumably linked to the most expressive oleate-coding loci. The carriers of each mutation were represented by ten unrelated inbreds. Another ten unrelated inbreds of common maize, which were not carriers of any of the above endosperm mutations, were used as controls.

Inbreds of common maize and inbred-carriers of endosperm mutations were grown for three years (2013, 2016, and 2017), during the largest differences in air temperatures during grain ripening over the last decade had occurred. According to observations of the Novaya Kakhovka Meteorological Station (synoptic index 33869), the average air temperature during grain ripening in 2013 was $19.9^{\circ} \mathrm{C}$, in $2016-21.7{ }^{\circ} \mathrm{C}$, and in $2017-23.1^{\circ} \mathrm{C}$ (http:// www.pogodaiklimat.ru/history/33869.htm).

When carrying out field experiments, we were guided by the generally accepted methods of field experiments (Dospekhov, 2011), taking into account the zonal features of growing maize in the steppe zone of Ukraine. To compensate for the deficiency of atmospheric moisture, the experiments were carried out under artificial irrigation with an irrigation rate of $4000 \mathrm{~m}^{3} / \mathrm{ha}$, and soil fertility was ensured by applying mineral fertilisers at a dose of $\mathrm{N}_{60} \mathrm{P}_{60} \mathrm{~K}_{45}$ (Likhovid, 2015).

Sowing of maize was carried out by hand planters in the third decade of April on ten nested plots with an area of $? ? 4.9 \mathrm{~m}^{2}$ in double repetition for each experimental variant of the experiment. Plots were placed in blocks of carriers of each endosperm mutation with randomised replication. The sowing pattern was dotted with a row spacing of $70 \mathrm{~cm}$ and a distance between plants in a row of $35 \mathrm{~cm}$. To eliminate weeds, Harnes soil herbicide was used at a dose of 2 1/ha. The plant stem density in sowing after emergence was 40 800 plants per hectare. Crop care consisted of inter-row cultivation and manual weeding. To obtain seeds within each plot, controlled cross-pollination of 3-4 female inflorescences with pollen collected from panicles of 5-6 other plants of the same plot was carried out. 
Obtaining of oil samples from freshly ground seeds was carried out by three-hour extraction with a petroleum ether fraction $40-60$ at a temperature of $30{ }^{\circ} \mathrm{C}$ and periodic shaking, and then the ether fraction was decanted and the solvent was completely evaporated in a moderate stream of nitrogen.

The fatty acid composition of the obtained preparations was analysed by the modified Peisker gas chromatographic method (Gutsol et al., 2015). The fatty acid composition of the obtained preparations was analysed by the modified Peisker gas chromatographic method (Gutsol et al., 2015). $30-50 \mu \mathrm{l}$ of isolated neutral lipids were introduced into thick-walled Pyrex glass ampoules, $2.5 \mathrm{ml}$ of a mixture of chloroform : methanol : sulfuric acid in a volume ratio of $100: 100: 1$ was poured into the ampoules and sealed. The transesterification of glycerol esters of fatty acids into methyl esters was carried out for three hours at a temperature of $100{ }^{\circ} \mathrm{C}$. After its completion, the ampoules were cooled to room temperature, opened, and quantitatively transferred into wide-necked test tubes. To a mixture of methyl esters of fatty acids in chloroform : methanol solvent, $2 \mathrm{ml}$ of $\mathrm{n}$-hexane, $2 \mathrm{ml}$ of water, and powdered zinc sulfate at the tip of a spatula were added, after which the contents of the ampoules were vigorously shaken and left until visible phase separation. After phase separation, the coloured hexane layer was decanted and filtered through a dense filter paper, on which 2-3 g of anhydrous sodium sulfate was applied.

The obtained mixture of methyl esters of fatty acids was subjected to separation on a two-channel gas-liquid chromatograph "Chrom-5" (company "KOVO", Czech Republic). Silanised diatomite Inerton-AW-DMCS with a grain size of $0.16-0.20 \mathrm{~mm}$ was used as a solid-phase carrier of the packed column, and diethylene glycol succinate was used as a liquid phase in an amount of $10 \%$ of the mass of the solid-phase carrier. High purity nitrogen was used as a gas-carrier. The volume of the sample to be separated was $2 \mu \mathrm{L}$.

The separation was carried out in stainless steel columns $250 \mathrm{~cm}$ in length and $3 \mathrm{~mm}$ in inner diameter. A flame ionisation detector was used. The separation mode was isothermal at $190{ }^{\circ} \mathrm{C}$. The evaporator temperature was 220 ${ }^{\circ} \mathrm{C}$, and detector temperature was $230{ }^{\circ} \mathrm{C}$. The carrier gas flow rate was $30 \mathrm{~cm}_{3} / \mathrm{min}$, the hydrogen flow rate through the detector burners was $35 \mathrm{~cm}_{3} / \mathrm{min}$, and the air flow rate was $350 \mathrm{~cm}_{3} / \mathrm{min}$.

Identification of the separated components was carried out by the retention time of their peaks, established using reliable standards of methyl esters of fatty acids manufactured by Sigma-Aldrich (USA). The content of each component in the mixture was determined by the ratio of the area under its peak to the sum of the areas under all peaks of the chromatogram.

The results were statistically processed by analysis of variance (Vukolov, 2008). Comparison of the means for the variants of the experiment was carried out using the least significant difference (LSD), which was calculated for the $5 \%$ significance level. Evaluation of genotype-environment interactions for oleate content was carried out using an environmental testing programme based on the EberhardRussell algorithm (Changizi et al., 2014). In the course of statistical processing, for each experimental variant, genotypic effects $\left(E_{i}\right)$, reflecting the average value of the trait for all years of testing, linear regression coefficients $\left(\mathrm{R}_{\mathrm{i}}\right)$, reflecting the response of the genotype to changes in growing conditions and variance of deviations from the regression line $\left(\mathrm{Si}_{2}\right)$, reflecting the reliability line plasticity estimates, were calculated. To establish the reliability of deviations from the regression line, the empirical value of the Cochran's G-criterion $\left(\mathrm{G}_{\text {fact. }}\right)$ was calculated and compared with the tabular value $\left(\mathrm{G}_{0.05}\right)$.

The inbred-carriers of each mutation were ranked according to the $\mathrm{E}_{\mathrm{i}}$ and $\mathrm{R}_{\mathrm{i}}$ values into three groups, in which the lowest rank was assigned to the inbreds with higher average levels of the trait and its lower dependence on growing temperature.

\section{RESULTS}

Oleate content in oils of common maize inbreds and inbreds - carriers of endosperm mutations. The obtained results showed that the inbreds-carriers of $s u_{1}$, ae and $s u_{2}$ endosperm mutations had significantly higher content of oleates in comparison with the inbreds of common maize (Table 1).

During the three years of study, the oleate content of inbred-carriers of the $s u_{1}$, $a e$, and $s u_{2}$ mutations was higher than in the inbreds of the common type by $61.9 \%, 26.9 \%$, and $45.4 \%$, respectively. However, at the same time, the oleate content varied within a fairly wide range within unrelated inbreds of common type and inbred-carriers of the same mutation.

Variability of the oleate content in inbreds of common type and inbred-carriers of endospermic mutations, depending on temperature during ripening. In each group of analysed inbreds, the lowest average oleate content was recorded in 2013 when temperatures were the lowest during grain ripening, and the highest in 2017 with the highest temperature (Table 2).

Table 1. Variability of oleate content in the oils of common maize inbreds and inbred-carriers of $s u 1, a e$, and su2 mutations; the results of evaluations of 10 inbreds of each type grown in 2013, 2016, and 2017

\begin{tabular}{l|c|c|c}
\hline \multirow{2}{*}{ Inbred types } & \multicolumn{3}{c}{ Oleate content in oil, \% } \\
\cline { 2 - 4 } & minimal & maximal & average \\
\hline Common type & 22.6 & 28.2 & 24.9 \\
Carriers of mutation su1 & 37.4 & 43.8 & 40.3 \\
Carriers of mutation ae & 28.2 & 35.2 & 31.6 \\
Carriers of mutation su2 & 33.4 & 38.3 & 36.2 \\
LSD 0,05 & 1.5 & & 1.2
\end{tabular}


Table 2. Average content of oleates in grain oil of common maize inbreds and inbred-carriers of $s u_{1}, a e$, and $s u_{2}$ mutations grown in 2013 and 2017; the results of evaluations of 10 inbreds of each type

\begin{tabular}{l|c|c|c}
\hline \multirow{2}{*}{ Inbred types } & \multicolumn{2}{|c|}{$\begin{array}{c}\text { Average oleate content by } \\
\text { years, } \%\end{array}$} & \multirow{2}{*}{ LSD $_{0.05}$} \\
\cline { 2 - 3 } & 2013 & 2017 & \\
\hline Common type & 24.5 & 25.4 & 0.5 \\
Carriers of mutation $s u_{1}$ & 39.7 & 41.0 & 0.5 \\
Carriers of mutation $a e$ & 31.0 & 32.4 & 0.6 \\
Carriers of mutation $s u_{2}$ & 35.7 & 36.8 & 0.5
\end{tabular}

The average content of oleates in 2016 in inbreds of each type either differed insignificantly from the level in 2013 , or the difference between the average in 2013 and 2016 approached statistical significance.

It was found that unrelated inbreds of common type and inbreds based on each mutation differed significantly both in average oleate content and in its variability under the influence of temperature during ripening.

Among the analysed inbreds of the common type, the inbreds with low genotypic effects in terms of oleate content (ranks 2 and 3) prevailed. Two inbreds (F-115 and W-153) had a significantly higher level of the trait (rank 1). The overwhelming majority of inbreds of the common type showed a fairly strong dependence on temperature fluctuations during the period of grain ripening, and the inbreds BC-70457 and P-523 showed a more stable content of oleates over the years of study, characterised by rank 1 (Table 3).

Similar patterns of variability in the oleate content were also displayed by the inbred-carriers the $s u_{l}$ mutation, in which the general level of the trait was higher than that of the inbreds of the common type (Table 4).

Most of inbreds of this type were distinguished by low genotypic effects on the content of oleates and its higher variability over the years, characterised by ranks 2 and 3 . Two inbred-carriers of the $s u_{1}$ mutation (MC-58 and MC-713) had higher average oleate content, described by rank 1, and two inbreds (MC-73 and MC-713) had higher stability of the trait. It is noteworthy that inbreds MC-73 and MC-713 had completely different ranks of genotypic effects, while inbred MC-713 combined high levels of

Table 3. Variability of oleate content in the oil of common maize inbreds, grown in 2013, 2016, and 2017

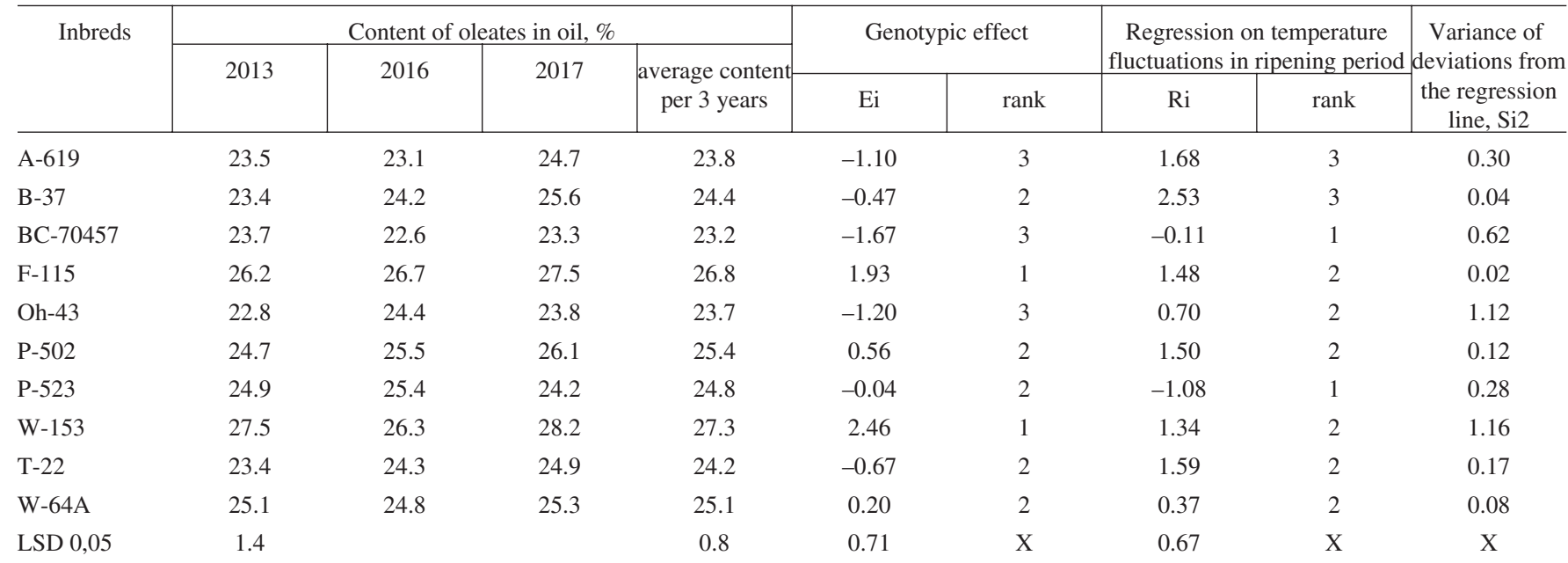

Table 4. Variability of oleate content in oil of maize inbred-carriers of the sul mutation, grown in 2013, 2016, and 2017

\begin{tabular}{|c|c|c|c|c|c|c|c|c|c|}
\hline \multirow[t]{3}{*}{ Inbreds } & \multicolumn{4}{|c|}{ Content of oleates in oil, $\%$} & \multirow{2}{*}{\multicolumn{2}{|c|}{ Genotypic effect }} & \multirow{2}{*}{\multicolumn{2}{|c|}{$\begin{array}{c}\text { Regression on temperature } \\
\text { fluctuations in ripening period }\end{array}$}} & \multirow{3}{*}{$\begin{array}{l}\text { Variance of } \\
\text { deviations from } \\
\text { the regression } \\
\text { line, } \mathrm{S}_{\mathrm{i}}{ }^{2}\end{array}$} \\
\hline & \multirow{2}{*}{2013} & \multirow{2}{*}{2016} & \multirow{2}{*}{2017} & \multirow{2}{*}{$\begin{array}{l}\text { average content } \\
\text { per } 3 \text { years }\end{array}$} & & & & & \\
\hline & & & & & $\mathrm{E}_{\mathrm{i}}$ & rank & $\mathrm{R}_{\mathrm{i}}$ & rank & \\
\hline MC-58 & 41.5 & 40.9 & 43.8 & 42.1 & 1.79 & 1 & 2.04 & 3 & 1.22 \\
\hline MC-73 & 39.3 & 37.8 & 37.4 & 38.2 & -2.11 & 3 & -1.36 & 1 & 0.47 \\
\hline MC-266 & 38.2 & 39.8 & 40.7 & 39.6 & -0.71 & 2 & 1.85 & 3 & 0.37 \\
\hline MC-270 & 37.7 & 38.6 & 39.6 & 38.6 & -1.64 & 3 & 1.45 & 2 & 0.04 \\
\hline MC-375 & 39.4 & 41.8 & 41.7 & 41.0 & 0.69 & 2 & 1.55 & 3 & 1.69 \\
\hline MC-380 & 39.2 & 40.7 & 40.4 & 40.1 & -0.18 & 2 & 0.77 & 2 & 0.77 \\
\hline MC-381 & 39.7 & 40.8 & 42.2 & 40.9 & 0.62 & 2 & 1.93 & 3 & 0.04 \\
\hline MC-401 & 40.4 & 40.1 & 41.2 & 40.6 & 0.29 & 2 & 0.72 & 2 & 0.21 \\
\hline MC-713 & 42.4 & 41.3 & 42.1 & 41.9 & 1.66 & 1 & -0.07 & 1 & 0.64 \\
\hline MC-719 & 39.3 & 39.6 & 40.7 & 39.9 & -0.41 & 2 & 1.13 & 2 & 0.02 \\
\hline $\operatorname{LSD}_{0,05}$ & 1.5 & & & 0.9 & 0.85 & $\mathrm{X}$ & õ0.53 & $\mathrm{X}$ & $\mathrm{X}$ \\
\hline
\end{tabular}


genotypic effects in terms of oleate content and the stability of this trait over the years.

Carriers of the ae mutation represented a rather homogeneous group in terms of oleate content, in which the majority of the inbreds showed the mean genotypic effects and responses to ripening temperatures, described by rank 2 (Table 5).

Two inbreds showed rank 3 for genotypic effects and two inbreds showed rank 3 for the effects of reactions on temperature during ripening. However, inbreds with higher genotypic effects and levels of stability of the trait over the years, described by rank 1, were also found in this group. Inbreds AE-456, AE-464, and AE-748 received rank 1 for genotypic effects, and inbreds AE-456 and AE-466 for the stability of the trait. The inbred AE-456 should be especially distinguished, as it had rank 1 both in the average level of the trait and of its stability over the years.

The group of inbred-carriers of the $s u_{2}$ mutation in terms of genotypic effects and responses to growing conditions was more heterogeneous than carriers of the ae mutation, and most of its inbreds received grades 2 and 3 for these characteristics (Table 6).

Inbreds AC-32 and AC-70 showed a higher average oleate content, while inbreds AC-32 and AC-43 had higher stability over the years. In both cases, these inbreds were evaluated with rank 1 . It is notable that the inbred AC-32 combined a high average level of the trait and its stability over the years.

In all analysed groups of inbreds, the variances of deviations from the regression line were rather low. The empirical values of the Cochran's criterion $\left(\mathrm{G}_{\mathrm{fact}}\right)$ for inbreds of the usual type, as well as inbred-carriers of the $s u_{1}$, ae and $s u_{2}$ mutations were $0.2967,0.3084,0.2189$, and 0.3333 , respectively, and in all cases were inferior to the table value $\left(\mathrm{G}_{0.05}=0.4450\right)$. Therefore, there is reason to believe that deviations of empirical data from the regression line are fairly uniform and random.

Table 5. Variability of oleate content in oil of maize inbred-carriers of the ae mutation, grown in 2013, 2016, and 2017

\begin{tabular}{|c|c|c|c|c|c|c|c|c|c|}
\hline \multirow[t]{3}{*}{ Inbreds } & \multicolumn{4}{|c|}{ Content of oleates in oil, $\%$} & \multirow{2}{*}{\multicolumn{2}{|c|}{ Genotypic effect }} & \multirow{2}{*}{\multicolumn{2}{|c|}{$\begin{array}{c}\text { Regression on temperature } \\
\text { fluctuations in ripening period }\end{array}$}} & \multirow{3}{*}{$\begin{array}{c}\text { Variance of } \\
\text { deviations from } \\
\text { the regression } \\
\text { line, } \mathrm{S}_{\mathrm{i}}{ }^{2}\end{array}$} \\
\hline & \multirow{2}{*}{2013} & \multirow{2}{*}{2016} & \multirow{2}{*}{2017} & \multirow{2}{*}{$\begin{array}{c}\text { average content } \\
\text { per } 3 \text { years }\end{array}$} & & & & & \\
\hline & & & & & $\mathrm{E}_{\mathrm{i}}$ & rank & $\mathrm{R}_{\mathrm{i}}$ & rank & \\
\hline AE-392 & 29.2 & 30.4 & 31.5 & 30.4 & -1.28 & 3 & 1.66 & 3 & 0.04 \\
\hline AE-456 & 33.1 & 31.9 & 33.3 & 32.8 & 1.12 & 1 & 0.25 & 1 & 1.09 \\
\hline AE-458 & 29.4 & 30.6 & 31.2 & 30.4 & -1.25 & 3 & 1.28 & 2 & 0.13 \\
\hline AE-464 & 33.1 & 32.8 & 34.4 & 33.4 & 1.79 & 1 & 1.02 & 2 & 0.47 \\
\hline AE-466 & 31.9 & 32.6 & 32.2 & 32.2 & 0.59 & 2 & 0.17 & 1 & 0.22 \\
\hline AE-746 & 30.7 & 30.2 & 32.1 & 31.0 & -0.65 & 2 & 1.11 & 2 & 0.77 \\
\hline AE-748 & 33.4 & 35.2 & 34.5 & 34.4 & 2.72 & 1 & 0.69 & 2 & 1.19 \\
\hline AE-750 & 28.2 & 30.6 & 30.4 & 29.7 & -1.91 & 3 & 1.49 & 2 & 1.46 \\
\hline AE-800 & 31.5 & 30.5 & 32.3 & 31.4 & -0.21 & 2 & 0.69 & 2 & 1.17 \\
\hline $\mathrm{LSD}_{0,05}$ & 1.8 & & & 1.0 & 0.93 & $X$ & 0.55 & $X$ & $X$ \\
\hline
\end{tabular}

Table 6. Variability of oleate content in oil of maize inbred-carriers of the $s u_{2}$ mutation, grown in 2013, 2016, and 2017

\begin{tabular}{|c|c|c|c|c|c|c|c|c|c|}
\hline \multirow[t]{3}{*}{ Inbreds } & \multicolumn{4}{|c|}{ Content of oleates in oil, $\%$} & \multirow{2}{*}{\multicolumn{2}{|c|}{ Genotypic effect }} & \multirow{2}{*}{\multicolumn{2}{|c|}{$\begin{array}{l}\text { Regression on temperature } \\
\text { fluctuations in ripening period }\end{array}$}} & \multirow{3}{*}{$\begin{array}{l}\text { Variance of de- } \\
\text { viations from } \\
\text { the regression } \\
\text { line, } \mathrm{S}_{\mathrm{i}}{ }^{2}\end{array}$} \\
\hline & \multirow{2}{*}{2013} & \multirow{2}{*}{2016} & \multirow{2}{*}{2017} & \multirow{2}{*}{$\begin{array}{c}\text { Average } \\
\text { content per } \\
3 \text { years }\end{array}$} & & & & & \\
\hline & & & & & $\mathrm{E}_{\mathrm{i}}$ & rank & $\mathrm{R}_{\mathrm{i}}$ & rank & \\
\hline AC-11 & 34.1 & 33.6 & 34.8 & 34.2 & -2.04 & 3 & 0.68 & 2 & 0.42 \\
\hline AC-13 & 35.3 & 36.1 & 37.5 & 36.3 & 0.09 & 2 & 1.92 & 3 & 0.01 \\
\hline AC-16 & 35.8 & 36.2 & 37.8 & 36.6 & 0.39 & 2 & 1.78 & 3 & 0.14 \\
\hline AC-28 & 34.7 & 35.4 & 37.6 & 35.9 & -0.31 & 2 & 2.57 & 3 & 0.19 \\
\hline AC-32 & 38.6 & 37.8 & 38.3 & 38.2 & 2.03 & 1 & -0.20 & 1 & 0.30 \\
\hline AC-37 & 35.5 & 35.7 & 36.6 & 35.9 & -0.27 & 2 & 0.98 & 2 & 0.05 \\
\hline AC-43 & 36.3 & 37.6 & 36.1 & 36.7 & 0.46 & 2 & -0.29 & 1 & 1.27 \\
\hline AC- 44 & 35.6 & 35.8 & 37.1 & 36.2 & -0.04 & 2 & 1.34 & 2 & 0.13 \\
\hline AC-52 & 33.4 & 34.7 & 34.8 & 34.3 & -1.91 & 3 & 1.16 & 2 & 0.33 \\
\hline AC-70 & 37.3 & 38.6 & 37.5 & 37.8 & 1.59 & 1 & 0.07 & 1 & 0.98 \\
\hline $\mathrm{LSD}_{0,05}$ & 1.4 & & & 0.8 & 0.71 & $X$ & 0.50 & & $X$ \\
\hline
\end{tabular}




\section{DISCUSSION}

The increased content of oleates in carriers of mutant genes $s u_{1}$, ae, and $s u_{2}$ can be considered as confirmation of the spatial linkage of these genes with oleate-coding loci and the presence of at least three oleate-coding loci in chromosomes 4, 5, and 6 .

Judging by the content of oleates, the most expressive loci among them are presumably located in the fourth and sixth chromosomes, and the least expressive in the fifth. The rest of the currently known oleate-coding loci, in particular those located on chromosomes 1 and 2 (Motto et al., 2010), cannot be characterised in this way, since none of the genes of the endosperm structure is localised in these chromosomes (Coe and Schaeffer, 2005).

The content of oleates in unrelated inbred-carriers of each endospermic mutation was notable as having the quantitative variability. The inbreds of the common type also showed quantitative variability in the content of oleates, although the level of the trait was significantly lower than in the mutant lines. The reason for the presence of such variability should be recognised as the effects of genotype and genotype-environment interactions.

It has been shown that the content of oleic acid glycerides in maize oil is regulated by a complex polygenic system, the main genes of which are localised in different chromosomes, exhibit different expressiveness, tendency to multiple allelism, interact between themselves not only in an additive, but also in an epistatic type, and influenced by modifier genes (Yang et al., 2010; Li et al., 2012). In addition, there is no guarantee of homozygosity for all loci that control oleic acid glycerides content in maize inbreds.

These features cause a free combination of alleles of oleate-coding loci, primarily unlinked with the genes of the endosperm structure, which, most likely, causes quantitative variability in oleate content.

It is noteworthy that in carriers of endospermic mutations, the range of quantitative variability in the content of oleates was significantly lower than the level of increase in the trait under the influence of endosperm mutations, especially $s u_{1}$ and $s u_{2}$. This can be considered as evidence of the high expressiveness of oleate-coding loci on chromosome 4 and 6 , which confirms the data of other authors (Belo et al., 2008; Wassom et al., 2008).

Another reason for the quantitative variability of the oleate content in carriers of endospermic mutations may be the crossover distribution of genes localised in linked oleatecoding loci and loci of the endosperm structure. In our experiments, during intralinear selection, we encountered some carriers of endospermic mutations with a very low oleate content, approaching the level of common maize. However, the frequency of their occurrence was very insignificant, and there was hardly any reason to associate the variability of the oleate content precisely with the crossing over effects.
The results obtained showed that the content of oleates in maize inbreds significantly depended on the climatic conditions of growing. Similar results were previously obtained by other authors (Egesel et al., 2011). It has been shown that among the environmental factors, the most significant effect on the content of oleates is the temperature regime of the growing season, especially during the period of grain ripening (Canvin et al., 2011). The oleate content increases with an increase in air temperature (Shulte et al., 2013).

In the framework of modern concepts, the mechanism of this phenomenon involves a decrease in the intensity of the formation of linoleic acid from oleic acid under the action of the desaturase FAD-2 (Li et al., 2015). It is known that one of the most important conditions for the desaturation process is a high content of molecular oxygen in tissues and organelles that synthesise fatty acids (Pelly, 2012). As the growing temperature rises, the oxygen concentration in these tissues and organs decreases, which, most likely, causes a decrease in FAD-2 desaturase activity and, as a consequence, an increase in the oleic acid content (Rolletschek et al., 2007).

The results obtained in our experiments confirmed this pattern. Under the conditions of 2017 with the highest growing temperature, in comparison with the conditions of 2013 with the lowest temperature, the average oleate content was higher in all groups of inbreds.

However, in the inbreds of all analysed types of maize, the content of oleates, depending on the growing temperature, did not change monotonically, and the reactions of different inbreds to this factor did not coincide. Most of the inbreds of the common type and inbred-carriers of each mutation were characterised by a wide range of genotype response to the temperature regime at time of ripening, and the content of oleates had rather pronounced variation over the years. At the same time, within each group, inbreds with narrow ranges of genotype response were identified, which had low plasticity and a fairly stable level of oleate content with fluctuations in temperatures during the ripening period.

Some inbreds with a narrow range of the genotype reaction combined stability of the trait over the years with its rather high genetically determined level. Inbreds of this type, most likely, have the greatest practical value for creating sources of maize oil with an increased content of oleic acid glycerides.

\section{CONCLUSIONS}

It was found that maize inbred-carriers of endospermic mutations $s u_{1}, a e$, and $s u_{2}$ differed from the inbreds of the common type by a significantly increased content of oleates in oil. According to three-year estimates, the inbred-carriers of the $s u_{1}$, ae and $s u_{2}$ mutations had higher oleate content than in inbreds of the common type by $61.9 \%, 26.9 \%$, and $45.4 \%$, respectively. With an increase in air temperature 
during the ripening period, the average oleate content in inbreds of all analysed types of maize, as a rule, increased. The level of the trait varied significantly in unrelated inbreds-carriers of one mutation, depending on the genotype and the nature of genotype-environment interactions. Most of the inbreds were distinguished by significant variability of oleate content over the years. At the same time, within each group, inbreds with low plasticity and a fairly stable oleate content at different ripening temperatures were identified, and some of them combined the stability of the trait over the years with its high genetically determined level.

\section{ACKNOWLEDGMENTS}

The authors express their deep gratitude to the team of the NASCO Breeding and Seed Production Station (Station Director Mr. Victor Muzhilko) for help in organising and conducting field experiments on the environmental testing of maize inbreds.

\section{REFERENCES}

Belo, A., Zheng, P., Luck, S., Shen, B., Meyer, D. J., Li, B., Tingey, S., Rafalski, A. (2008). Whole genome scan detects an allelic variant of $\mathrm{fad} 2$ associated with increased oleic acid levels in maize. Mol. Genet. Genom., 279 (1), 1-10.

Boyer, C. D, Hannah, L. C. (2001). Kernel mutants of maize. In: Hallauer, A. R. (Ed.). Specialty maizes. $2^{\text {nd }}$ edn. CRC Press, Boca Raton-LondonNew-York-Washington D.C., pp. 8-38.

Canvin, D. T. (2011). The effect of temperature on the oil content and fatty acid composition of the oils from several oil seed crops. Canad. J. Bot., 43 (1), 63-69.

Changizi, M., Choucan, R., Heravan, E. M., Bihamta, M. R., Darvish, F. (2014). Evaluation of genotype_environment interaction and stability of maize hybrids and relationship among univariate parametric methods. Canad. J. Plant Sci., 94 (7), 1255-1267.

Coe, E. H., Schaeffer, M. L. (2005). Genetic, physical, maps, and database resources for maize. Maydica, 50 (3), 285-303.

Cook, J. P., McMullen, M. D., Holland, J. B., Tian, F., Bradbury, P., Ross-Ibarra, J., Buckler, E. S., Flint-Garcia, S. A. (2012). Genetic architecture of maize kernel composition in the nested association mapping and inbred association panels. Plant Physiol., 158 (2), 824-834.

Dar, A. A., Choudhury, A. R., Kancharla, P. K., Arumugam, N. (2017). The FAD2 gene in plants: Occurrence, regulation, and role. Front. Plant Sci., 8 , 1789.

De Alzaa, F., Guillaume, C., Ravetti, L. (2018). Evaluation of chemical and physical changes in different commercial oils during heating. Acta Sci. Nutr. Health, 2 (6), 2-11

Dospekhov, B. A. (2011). Techniques of Field Experiment (With the Basics of Statistical Processing of Research Results) [Доспехов, Б. А. Методика полевого опыта (с основами статистической обработки результатов исследований)]. $6^{\text {th }}$ edn. Alliance, Moscow. 350 pp. (in Russian).

Egesel, C. O., Kahriman, F., Gul, M. K. (2011). Discrimination of maize inbreds for kernel quality traits and fatty acid composition by a multivariate technique. Acta Sci. Agron., 33 (4), 613-620.

Gavrilova, V., Shelenga, T., Porokhovinova, E., Dubovskaya, A., Kon'kova, N., Grigoryev, S., Podolnaya, L., Konarev, A., Yakusheva, T., Kishlyan, N., Pavlov, A., Brutch, N. (2020). The diversity of fatty acid composition in traditional and rare oil crops cultivated in Russia. Bio. Comm., 65 (1), $68-81$
Gutsol, V. V., Zhuravel, I. A., Guryeva, I. G., Kislichenko, V. S. (2015). The studGutsol, V. V., Zhuravel, I. A., Guryeva, I. G., Kislichenko, V. S. (2015). The study of fatty acids in the seeds of lettuce variety "Lollo Rosso" [Гуцол, В. В., Журавель, И. А., Гурьева, И. Г., Кисличенко, В. С. Изучение жирных кислот в семенах салата сорта «Лолло Россо»]. Bulletin of the Kazakh National Medical University, 4, 476-478 (in Russian).

Karakor, K., Cam, M. (2015). Effects of oleic acid. Med. Sci. Discov., 2 (1), $125-132$.

Leao, J. D., Bouillon, V., Muntada, L., Johnson, C., Wilson, P., Vergness, O., Dano, C., Igartua, A., Mendoza, G. (2016). New formulations of sunflower based bio-lubricants with high oleic acid content - VOSOLUB project. Oils \& Fats Crops Lipids, 23 (5), D 509.

Li, H., Peng, Z., Yang, X., Wang, W., Fu, J., Wang, J., Han, Y., Chai, Y., Guo, T., Yang, N., Liu, J., Warburton, M. L., Cheng, Y., Hao, X., Zhang, P., Zhao, J., Liu, Y., Wang, G., Li, J., Yan, J. (2012). Genome-wide association study dissects the genetic architecture of oil biosynthesis in maize kernels. Nature Genet., 45 (1), 43-50.

Li, Q., Zheng, Q., Shen, W., Cram, D., Fowler, D. B., Wei, Y., Zou, J. (2015). Understanding the biochemical basis of temperature-induced lipid pathway adjustments in plants. The Plant Cell, 27 (1), 86-103.

Likhovid, P. V. (2015). Sweet maize Cultivation Technology Under the Irrigated Conditions (scientific-production edition) [Лиховид, П. В. Технология выращивания кукурузы сахарной на поливных землях (научно-производственное издание)], Diamond trading tour, Warszawa. 52 pp. (in Russian).

Long, W., Hu, M., Gao, J., Chen, S., Zhang, J., Cheng, L., Pu, H. (2018) Identification and functional analysis of two new mutant BnFAD2 alleles that confer elevated oleic acid content in rapeseed. Front. Genet., 9, 399

Menard, G. N., Moreno, J. M., Bryant, F. M., Munoz-Azcarate, O., Kelly, A. A., Hassani-Pak, K., Kurup, S., Eastmond, P. J. (2017). Genome wide analysis of fatty acid desaturation and its response to temperature. Plant Physiol., 173 (3), 1594-1605.

Motto, M., Balconi, C., Hartings, H., Rossi, V. (2010). Gene discovery for improvement of kernel quality-related traits in maize. Genetica, 42 (1), 23-56

Murphy, D. J. (2014). Using modern plant breeding to improve the nutritional and technological qualities of oil crops. Oils. Fats Crops Lipids, 21 (6), D 607

Parcell, J., Kojima, Y., Roach, A., Cain, W. (2018). Global edible vegetable oil market trends. Biomed. J. Sci. Tech. Res., 2 (1), 2282-2291.

Pelly, J. (2012). Fatty acid and triglyceride metabolism. In: Pelly, J. Elsevier's Integrated Review Biochemistry. $2^{\text {nd }}$ edn. Elsevier, Philadelphia, PA, pp. $81-88$.

Rajendran, A., Chaudhary, D., Mahajan, V. (2017). maize oil research and improvement: Review. J. Crop Weed, 13 (2), 247-252.

Rolletschek, H., Borisjuk, L. Sanchez-Garcia, A., Gotor, C., Romero, L. C., Martinez-Rivas, J. M., Mancha, M. (2007). Temperature-dependent endogenous oxygen concentration regulates microsomal oleate desaturase in developing sunflower seeds. J. Exp. Bot., 58 (12), 3171-3181.

Shulte, L., Ballard, T., Samarakoon, T., Yao, L., Valdani, L., Staggenborg, P., Rezac, M. (2013). Increased growing temperature reduces content of polyunsaturated fatty acids in four oilseed crops. Industr. Crops Products, $51(2), 212-219$

Vanhercke, T., Wood, C. C., Stymme, S., Singh, S. P., Green, A. G. (2013) Metabolic engineering of plant oils and waxes for use as industrial feedstocks. Plant Biotechnol. J., 11 (2), 197-210.

Vukolov, E. A. (2008). Foundations of Statistical Analysis. Workshop on Statistical Methods and Operations Research Using the Statistica and Exel Packages: Tutorial [Вуколов Э. А. Основы статистического анализа. Практикум по статистическим методам и исследованию операций с помощью пакетов Statistica и Excel: учебное пособие]. $2^{\text {nd }}$ edn. Forum, Moskow, 464 pp. (in Russian). 
Wassom, J. J., Mikkilineni, V., Bohn, M. O., Rocheford, T. R. (2008). QTL for fatty acid composition of maize kernel oil in Illinois High Oil $\times$ B73 backcross-derived lines. Crop Sci., 48 (1), 69-78.

Wilson, R. F. (2012). The role of genomics and biotechnology in achieving global food security for high-oleic vegetable oil. J. Oleo. Sci., 61 (7), 357-367.

Yang, X., Guo, Y., Yan, J., Zhang, J., Song, T., Rocheford, T., Li, J.-S. (2010). Major and minor QTL and epistasis contribute to fatty acid compo-

Received 25 November 2020

Accepted in the final form 29 May 2021 sitions and oil concentration in high-oil maize. Theor. Appl. Genet. 120 (3), 665-678.

Yara-Varon, E., Li, Y., Barcells, M., Canela-Garayoa, R., Fabiano-Tixier, A.-S., Chemat, F. (2017). Vegetable oils as alternative solvents for green oleo - extraction, purification and formulation of food and natural products. Molecules, 22, 1474.

Zhao, X., Wei, J., He, L., Zhang, Y., Zhao, Y., Xu, X., Wei, Y., Ge, S., Ding, D., Liu, M., Gao, S., Xu, J. (2019). Identification of fatty acid desaturases in maize and their differential responses to low and high temperature. Genes, 10, 445.

\section{OLEĪNSKĀBES GLICERĪDU SATURS KUKURŪZAS ENDOSPERMAS MUTANTU ELL Ā UN TĀ ATKARĪBA NO TEMPERATŪRAS NOBRIEŠANAS LAIKĀ}

Glicerīdu saturs eḷıā ir atkarīgs no kukurūzas līniju genotipa. Daḷai līniju šis saturs palielinās līdz ar temperatūras paaugstināšanos, citām līnijām tas paliek stabils. 